\title{
$\mathrm{LED}$ 및 자이로센서를 이용한 다기능 전자측량기준점 프로토타입 시스템의 성능비교에 관한 연구 박성균 ${ }^{*}$. 정세훈 ${ }^{* *}$. 박동국 ${ }^{* * *}$. 심춘보 ${ }^{* * * *}$
}

\section{A Study on Performance Comparison of Multipurpose Function Electronic Measurement Reference Station Prototype System using LED and Gyro Sensor}

\author{
Sung-Kyun Park ${ }^{*} \cdot$ Se-Hoon Jung ${ }^{* *} \cdot$ Dong-Gook Park $^{* * *} \cdot$ Chun-Bo Sim ${ }^{* * * * *}$ \\ 요 약
}

본 논문에서는 기존에 매설된 기준점의 문제점을 분석 및 보완하기 위해서 경관 조명, 실시간 데이터 수집, 주변 지각변동의 모니터링이 가능한 LED 및 자이로센서 기반의 다기능 전자측량기준점 프로토타입 시스템을 제안한다. 제안하는 시스템의 $\mathrm{H} / \mathrm{W}$ 는 지각변동 감지를 위해서 자이로센서모듈을 탑재하고, 위치정보를 처리하 기 위한 GPS모듈, 전자측량기준점의 주변 환경 데이터를 처리하기 위한 환경 센서 모듈을 이용하여 센서값 을 데이터화하고 수집된 데이터를 $\mathrm{CDMA}$ 무선 통신으로 서버로 전송이 가능하도록 하였다. 아울러 전자측량 기준점의 $\mathrm{H} / \mathrm{W}$ 활용을 높이기 위해 전자측량기준점 $\mathrm{H} / \mathrm{W}$ 의 외관에 $\mathrm{LED}$ 및 $\mathrm{QR}$ 코드, $\mathrm{RFID}$, 태양광모듈을 적 용시켜 시스템 관리 및 사후 활용성 높이고자 한다. 마지막으로 본 논문에서 제안한 다기능 전자측량기준점 에 다양한 기능이 포함되어 있어 안정적인 전력 공급을 위한 전류량 평가를 실시하였고, 측정 결과 전력 소실 률이 $2.29 \%$ 로 비교적 안정적인 운영이 가능한 결과를 확인하였다. 그리고 제안된 전자측량기준점의 우수성을 평가하기 위해 기존에 연구된 전자측량기준점 시스템과의 정성적인 비교평가를 실시하였다.

\section{ABSTRACT}

In this paper, We proposes multipurpose function electronic measurement reference station prototype system based on LED and Gyro Sensor. This system have developed to possible with real time data collection and landscape illumination and surrounding diastrophism monitoring for that analyze problems of existing planted reference station. Hardware for the proposed system consists of a gyro sensor module to detect diastrophism ,GPS module to process location information, environment sensor module to process surrounding environmental data and CDMA wireless data communication to send the collected data to server. In addition, this paper intends to enhance system management and future usability in a way that applies LED, QR-code, RFID and Solar cell module to outer side of electronic measurement reference station to improve usability of $\mathrm{H} / \mathrm{W}$ for electronic measurement reference station. Lastly, this paper conducted current amount evaluation to supply stabilized electricity with its various functions in the proposed multipurpose function electronic measurement reference station and it's proved that this system can be stably operated with its electricity loss factor of $2.29 \%$ loss factor. And this paper conducted a qualitative comparison with existing electronic measurement reference station system in order to evaluate superiority of the proposed electronic measurement reference station.

$$
\text { 키워드 }
$$

Electronic Measurement Reference Station, LED, Gyro Sensor, QR-Code, RFID 전자측량기준점, 발광다이오드, 자이로센서, $\mathrm{QR}$-코드, RFID

* 순천대학교 멀티미디어공학과 석사과정(psk1227@ nate.com)

** 순천대학교 멀티미디어공학과 박사과정(iam1710@ hanmail.net)

*** 순천대학교 정보통신공학과 부교수(dgpark6@sunchon.ac.kr)

**** 교신저자(corresponding author) : 순천대학교 멀티미디어공학과 부교수(cbsim@sunchon.ac.kr)

접수일자 : 2013. 0610

심사(수정)일자 : 2013. 07. 23

게재확정일자 : 2013. 08. 23 


\section{I. 서 론}

정부 및 민간단체는 지리정보시스템을 다양하게 연 구하고 있다[1-3]. 특정 위치를 측위하거나 측정하기 위해서는 해당 지점의 경·위도 좌표를 활용한다. 국내 에서는 이러한 경·위도 좌표를 지난 1910년 이후 동 경 측지계를 기반으로 사용하였고 현재까지 지리정보 시스템 및 위치 정보를 활용하는 전자측량기준점에도 동경 측지계를 활용해 오고 있다.

그러나 동경 측지계는 세계 측지계와 많은 오차를 가지고 있을 뿐더러 세계 측지계로 변환을 위한 많은 예산 및 시간이 소비된다. 따라서 정부는 2010년 전 자법 개정에 따라 국제표준의 세계 측지계로 전환사 업 추진을 하게 되었다. 이에 전자법, 지적법, 수로 업 무법으로 나누어진 개별기준점들과 지역별로 나누어 진 지역 측지계(동경 측지계)를 세계 측지계로 변환 작업을 시급하게 요구하고 있다. 그리고 현재 자치도 별로 세계 측지계 변환 및 개별기준점의 혼선의 문제 점을 해결하기 위해 다기능 전자측량기준점설치를 확 대하고 있는 실정이다[4-5].

또한 2011년 동일본 지진의 영향으로 대한지적공사 지적연구원에서 전자측량기준점의 조사결과 국내 지 표면의 GPS기준점들이 많이 틀어졌다. 기준점의 변 환은 지진과 같은 지각의 변화가 원인이 되기도 하지 만 지하수 사용 및 광석의 채취와 무분별한 개발로 인한 싱크홀(SinkHole)과 지반침하 현상이 발생되어 기준점의 위치 또한 안정적이지 못하다.

기존에 활용된 국가 기준점들 경위도원점(=측지원 점), 수준원점, 절대중력원점, 중력기준점, 중력보조기준 점, 삼각점, 수준점, 지적기준점, 전자측량기준점이 있 다. 전자측량기준점 설계 및 개발을 하기 위해서는 목 적별로 기준점의 기능과 제공받는 정보가 달라 시스템 을 구성할 때 마다 요구사항을 분석하고 설계하는 과 정이 반복이 되므로 개발에 대한 투자비가 증가 되는 실정이다. 또한 기준점의 외형을 활용할 수 있는 형태 는 전무하며 현재 개발되는 전자측량기준점의 외형 역 시 개발 후 활용되기 위한 기능을 전무한 상태이다.

본 논문에서는 사유지 측량 및 공공 측량의 목적으 로 사용되던 기존의 기준점 관리의 문제점을 보완 및 개선하기 위해 경관 조명 및 실시간 데이터 수집 및 주변 지각변동의 모니터링이 가능한 $\mathrm{LED}$ 및 자이로
센서 기반의 다기능 전자측량기준점 프로토타입 시스 템을 제안한다. 제안하는 시스템의 $\mathrm{H} / \mathrm{W}$ 는 지각변동 감지를 위해서 자이로센서 모듈을 탑재하고, 위치정보 를 처리하기 위한 GPS모듈, 전자측량기준점의 주변 환경 데이터를 처리하기 위한 환경 센서 모듈을 이용 하여 센서값을 데이터화하고 수집된 데이터를 $\mathrm{CDMA}$ 무선 통신으로 서버로 전송이 가능하도록 하였다. 아 울러 전자측량기준점의 $\mathrm{H} / \mathrm{W}$ 활용을 높이기 위해 전 자측량기준점 $\mathrm{H} / \mathrm{W}$ 의 외관에 $\mathrm{LED}$ 및 $\mathrm{QR}$ 코드, $\mathrm{RFID}$, 태양광 모듈을 적용시켜 시스템 관리 및 사후 활용성 높이고자 한다. 마지막으로 본 논문에서 제안한 다기 능 전자측량기준점에 다양한 기능이 포함되어 있어 안정적인 전력 공급을 위한 전류량 평가를 실시하였 고, 제안된 전자측량기준점의 우수성을 평가하기 위해 기존에 연구된 전자측량기준점 시스템과의 정성적인 비교 평가를 실시하였다.

\section{II. 관련 연구}

2장에서는 본 연구와 관련된 기존 전자측량기준점 의 관련 연구로 아래 6 가지 연구를 언급한다.

[4]에서는 지표상의 전자측량기준점에 위치하여 기 준점의 정보와 위치를 송신하는 전자측량기준점과 기 준점 관리서버, 관련 서비스로 구성한 시스템을 연구 하였다. 또한 $\mathrm{RFID}$ 태그를 전자측량기준점에 부착하여 기준점의 고유 $\mathrm{ID}$ 를 부여함으로써 관리를 가능하도록 하였고, 원격서버로 GPS 위치 데이터 전송이 가능하 도록 시스템을 연구하였다.

[5]의 연구에서는 기준점의 효율적인 관리에 대한 방법을 제안하고 있다. 통합 기준점 설계 시 관리업무 분석 및 요구사항 분석, 데이터의 입력, 갱신, 검색, 네트워크 분석, 통계 기능 등 기존 사용자의 요구사항 을 반영하여 체계적인 시스템 설계를 제안하였고, Mapobject를 엔진으로 Visual $\mathrm{C}++^{+}$, Visual Basic을 기반으로 $1 / 5,000$ 수치지도와 수치지적도면을 이용하 여 통합 관리 시스템을 구축하였다. 제안된 통합 관리 시스템을 통해 도형정보 및 속성정보, 위치정보들을 제공하는 기능을 구현하였다.

[6]의 연구는 RFID 및 $\mathrm{QR}-\mathrm{Code}$ 를 이용한 국가기 준점 원격 모니터링 웹 시스템에 관한 부분을 진행한 
연구이다. 외부에 설치되는 국가기준점의 특성상 $\mathrm{RFID}$ 및 $\mathrm{QR}-$ Code의 파손을 최소화할 수 있는 태그 를 부착하는 점을 착안하였고, 해당 $\mathrm{RFID}$ 및 $\mathrm{QR}$-Code를 이용한 기준점 현장관리 시스템 및 기준 점 통합관리 시스템을 제안하였다. 해당 연구에서 제 안한 국가기준점 현장관리 시스템의 하드웨어는 PDA 에 RFID 리더기, $\mathrm{QR}$ 코드 스캐너, $\mathrm{GPS}$ 수신기, $\mathrm{CDMA}$ 모듈로 구성되어 있다. 소프트웨어는 Windows $\mathrm{CE}$ 를 기반으로 개발하였다. $\mathrm{RFID}$ 태그 및 $\mathrm{QR}$ 코드를 인식하고, GPS 신호를 수신하여 단말기의 위치를 지 도상에 표현할 수 있으며, $\mathrm{CDMA}$ 모듈을 통해 통합관 리서버와 데이터를 송수신 할 수 있도록 하였다. 그리 고 국가기준점 통합관리 웹 시스템은 모바일 웹 서버 와 국가기준점 $\mathrm{DB}$ 로 구성되어 있으며, 인터넷이나 모 바일 웹 환경에서 접속이 가능하도록 되어 있다.

\section{III. 제안하는 다기능 전자측량기준점 프로타타입 시스템}

3 장에서는 기존에 개발된 전자측량기준점의 기능성 과 활용성의 문제점 비교 평가하여, 보완된 다기능 전 자측량기준점 프로토타입 시스템을 제안한다[7].

\section{1 다기능 전자측량기준점 구조도}

본 논문에선 제안하는 다기능 전자측량기준점 시스템 은 전자측량기준점 $\mathrm{H} / \mathrm{W}$ 의 주변의 센서값에 변화를 측정 하고 전자측량기준점의 외관 활용성을 극대화하기 위한 여러 가지 환경 요소들을 고려하여 설계 및 개발한다.

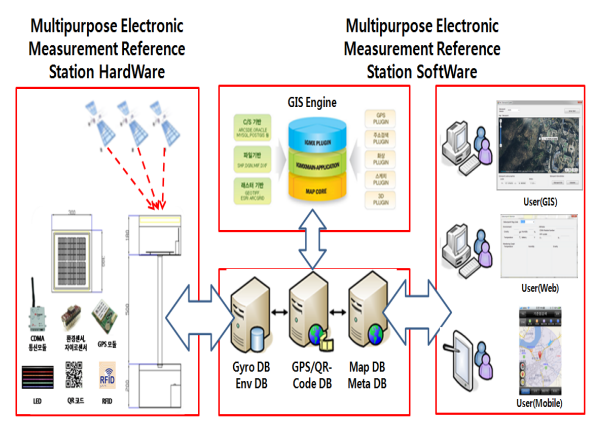

그림 1. 다기능 전자측량기준점 시스템 구성도

Fig. 1 Structure of multipurpose function electro nic measurement reference station system
그림 1 의 전자측량기준점 시스템의 구조는 전자측 량기준점 $\mathrm{H} / \mathrm{W}$ 와 전자측량기준점 $\mathrm{S} / \mathrm{W}$ 로 이루어져있 다. 다기능 전자측량기준점은 주기적인 전력 공급이 필요한 산간지역과 같은 원격지에 설치되기 위한 무 선 자가 전력 모듈, 전자측량기준점에 해당 지점의 좌 표 값 측정을 위한 GPS모듈과 손.망실에 대비하기 위한 지각변동의 감지를 측정하는 자이로센서 모듈, 다기능 전자측량기준점의 고유 $\mathrm{ID}$ 를 구분하기 위한 $\mathrm{QR}$ 코드 및 $\mathrm{RFID}$ 태그가 포함된 태깅모듈, 그리고 환 경 값을 반영하기 위해 온·습도 센서를 포함한 환경 센서 모듈, 전자측량기준점 외형의 미관적인 활용성을 높이기 위한 $\mathrm{LED}$ 모듈, 마지막으로 각종 모듈을 통해 수집된 데이터들은 시스템 서버로 전송하기 위한 $\mathrm{CDMA}$ 무선 통신 모듈로 제안하는 다기능 전자측량 기준점 $\mathrm{H} / \mathrm{W}$ 는 총 7 가지의 모듈로 구성된다. 시스템 서버는 전자측량기준점의 데이터를 받기위해 소켓통 신의 포트를 열어 대기상태에 있게 된다. 서버는 다기 능 전자측량기준점에서 데이터를 전송받아올 때 데이 터를 파싱하게 되는데 등록된 전자측량기준점별로 데 이터를 저장하게 된다. 시스템에서는 서버에 등록되지 않은 전자측량기준점의 데이터는 데이터베이스에 저 장하지 않는다. 그리고 분석 및 저장된 데이터로 전자 측량기준점의 정보와 전자 값을 제공받을 사용자에게 시스템 UI를 통해 제공받게 된다.

\section{2 다기능 전자측량기준점 $\mathrm{H} / \mathrm{W}$ 외형 설계}

외부 환경에 설치될 다기능 전자측량기준점형태를 갖추기 위해서 그림 2 와 같은 형태로 설계하였다.

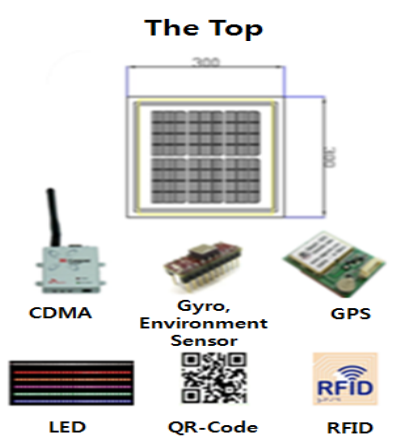

The Whole

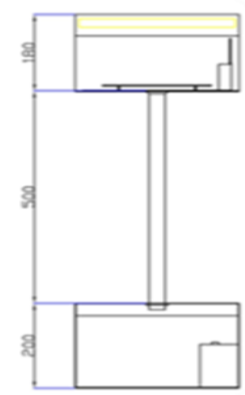

그림 2. 다기능 전자측량기준점 $\mathrm{H} / \mathrm{W}$ 설계

Fig. 2 Design of multipurpose function electronic measurement reference station hardware 
상단에 데이터를 수집하기 위한 각 센서와 모듈이 설계된 $\mathrm{PCB}$ 기판과 전자측량기준점의 자가 전력을 공 급하기 위한 태양광모듈을 배치하도록 설계하였다. 그 림 2 와 같이 전자측량기준점 $\mathrm{H} / \mathrm{W}$ 는 옥외에 매설하고 설치될 것을 고려하였으며 견고한 형태의 구조물을 갖추게 하였다. GPS 수신값의 정확도를 위해 지상에 서 1미터 높이로 위치하게 설계하였다. 무선 수신 방 식은 $\mathrm{CDMA}$ 모듈로 설계하였고, 태양열전지를 이용해 상시적으로 전원을 공급받을 수 있도록 태양광모듈패 널과 발전기, 충전지를 내장하도록 하였다. 또한 전자 측량기준점에 대한 일반인들의 인식을 극대화하고 외 형의 활용성을 높이기 위해 $\mathrm{LED}, \mathrm{QR}$ 코드, $\mathrm{RFID}$ 를 내장하도록 한다. 마지막으로 다기능 전자측량기준점 메인 컨트롤 보드에는 시스템 서버와 통신을 위한 $\mathrm{CDMA}$ 통신 모듈, 위성 측량을 위한 GPS모듈, 지각변 동에 의한 각속도 발생 측정을 위한 기준점 자이로센 서 모듈, 기준점 환경(온도·습도)값을 수집하기 위한 환경 센서 모듈을 포함하도록 설계하였다.

\section{3 메인 컨트롤 보드 $(\mathrm{MCU})$ 설계}

본 논문에서 제안하는 다기능 전자측량기준점에 활 용될 전자측량기준점 메인보드는 $\mathrm{H} / \mathrm{W}$ 설계 과정에 따라 AutoCad를 통한 회로도 작성과 작성된 회로도 를 바탕으로 $\mathrm{PCB}$ (Printed Circuit Board) Artwork 형 태의 파일을 설계하였다. 그림 3 은 메인 컨트롤 보드 의 회로도 설계 화면이다.

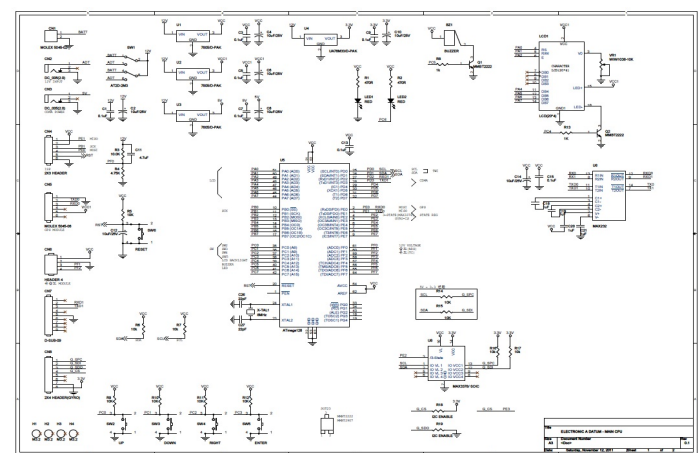

그림 3. 메인 컨트롤 보드 회로도의 설계

Fig. 3 Design of main control board circuit diagram

전자측량기준점의 메인보드는 Atmega128 CPU를 사용하여 $\mathrm{LCD}, \mathrm{GPS}$ 모듈, 자이로센서 모듈, 온·습도
센서 모듈LED모듈, $\mathrm{CDMA}$ 통신 모듈의 컨트롤을 통 합 처리하였다. 자이로센서와 온·습도 센서 모듈은 CPU와 UART(TTL) RS232의 통신 방식으로 신호 데이터값을 받는다. 자가 전력을 위한 태양광모듈에서 $18 \mathrm{~V}$ 의 전압을 가진 전력을 받아 충전기에서 $12 \mathrm{~V}$ 로 변환하여 충전할 수 있도록 메인보드에서 제어가 가 능하도록 하였다. 그리고 이것을 전자측량기준점 메인 보드에 공급한다. 태양열충전이 이뤄지지 않는 저녁시 간대에 충전된 배터리의 전력이 공급되도록 고려하였 다. 그림 4는 회로도를 바탕으로 설계된 메인 컨트롤 보드 Artwork의 화면이다.

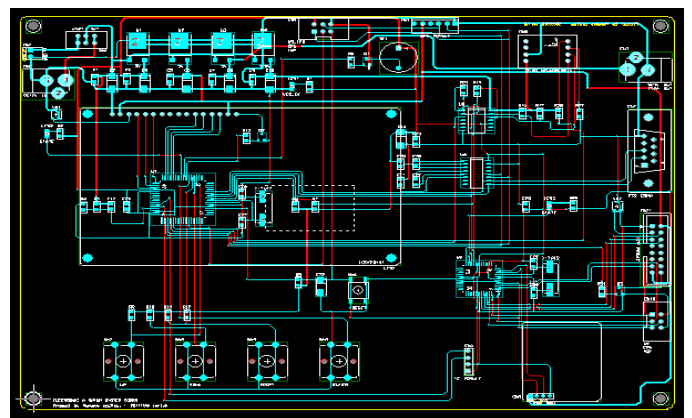

그림 4. 메인 컨트롤 보드의 아트워크 설계

Fig. 4 Artwork design of main control board

전자측량기준점 메인보드에서는 전압의 균형적인 안정을 위해 $\mathrm{CPU}, \mathrm{LCD}, \mathrm{CDMA}$ 로만 전원을 공급하 도록 하였다. 모듈별로 $\mathrm{CPU} 5 \mathrm{~V}, \mathrm{LCD} 12 \mathrm{~V}, \mathrm{CDMA}$ $5 \mathrm{~V}$ 의 전압이 공급되도록 설계하였다. 자이로센서, 환 경 센서, $\mathrm{GPS}, \mathrm{LED}$ 모듈은 $\mathrm{CPU}$ 와 동시에 전원공급을 받도록 하였으며, $\mathrm{CPU}$ 의 정상적인 작동확인을 위해 $\mathrm{LCD}$ 를 삽입하였다. 특히 $\mathrm{LED}$ 모듈은 본 시스템의 $\mathrm{CPU}$ 상에서 가장 많은 전력 공급이 필요한 것으로 입력되는 전력과 $\mathrm{LED}$ 모듈로 출력되는 전력의 균형화 를 위해 출력 전력의 전압을 일정이상 증가 시 작동 이 되지 않도록 설계하였다. 그림 5 는 $\mathrm{LED}$ 출력 단 자의 회로도 설계화면이다. 또한 메인 컨트롤 보드에 는 초기 작동 시 BUZZER를 삽입하여 부팅 시 확인 을 하도록 하였다. 현장에서 기준점의 동작 상태와 데 이터 값을 확인할 수 있도록 스위치를 달아 페이지 넘김 방식으로 하나의 $\mathrm{LCD}$ 에 모든 정보를 담도록 설 계하였다. 

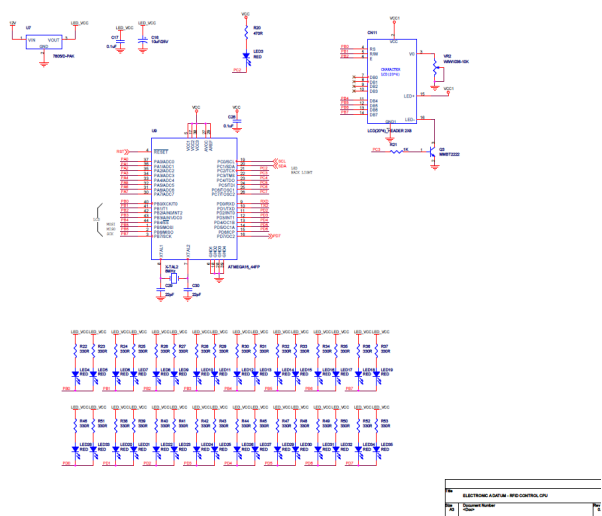

그림 5. LED 출력 회로도 설계

Fig. 5 Design of LED output circuit diagram

\section{4 자가 전력 공급 설계}

제안하는 다기능 전자측량기준점 $\mathrm{H} / \mathrm{W}$ 는 원격지에 매설되는 특징으로 인해 지속적인 전력 공급이 어려 운 단점을 태양광모듈을 이용한 자가 전력 공급으로 처리하였다. 그림 6 은 태양광모듈의 배터리 충전식 설 계도이다.

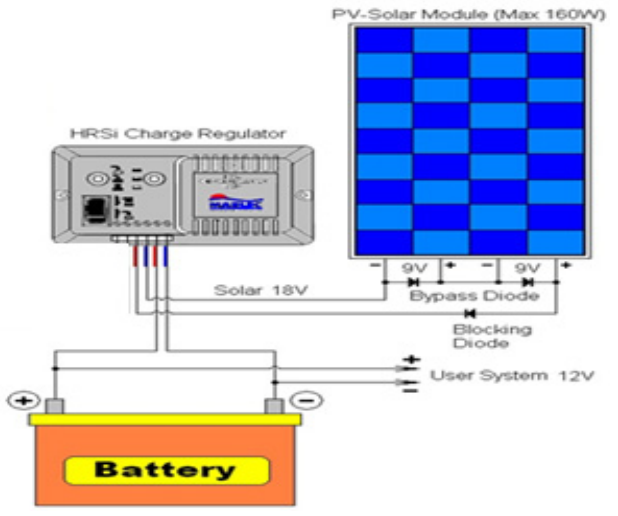

그림 6. 태양광모듈의 배터리 충전 설계

Fig. 6 Design of solar cell battery charge

태양광 에너지를 수집하여 전기 에너지로 변환 후 에너지를 배터리에 보관하는 형태이다. 전원 공급 장 치를 바탕으로 전력소비량을 계산하면 소비 전력은 $255 \mathrm{~mW}$ 이고, 공급 전력은 최대 $1.8 \mathrm{~W}$ 이다. 최대 충전 까지는 약 7 시간이 소요되며, 최대 충전 시 작동시간 은 126 시간이 가능하도록 설계한다.

\section{$\mathrm{VI}$. 구현 및 성능 평가}

\section{1 다기능 전자측량기준점 프로토타입 $\mathrm{H} / \mathrm{W}$}

그림 7 은 본 논문에서 제안한 다기능 전자측량기준 점 $\mathrm{H} / \mathrm{W}$ 의 전제적인 외형이다.

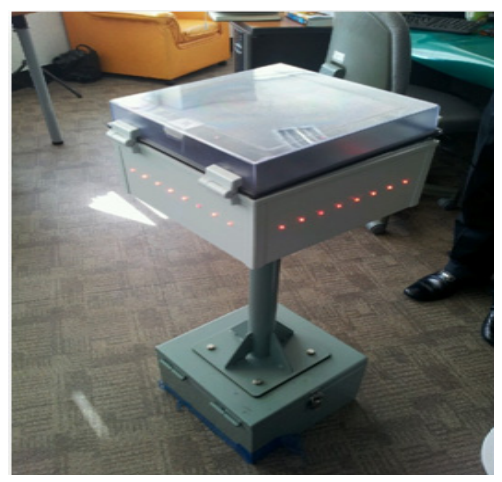

그림 7. 다기능 전자측량기준점 외형

Fig. 7 Appearance of multipurpose electronic measurement reference station

다기능 전자측량기준점의 상세적인 설명은 다음과 같다. 그림 8과 같이 전자측량기준점 상단에는 Solar cell과 $\mathrm{MCU}$ 를 담고 있는 패널박스를 가지고 있다.

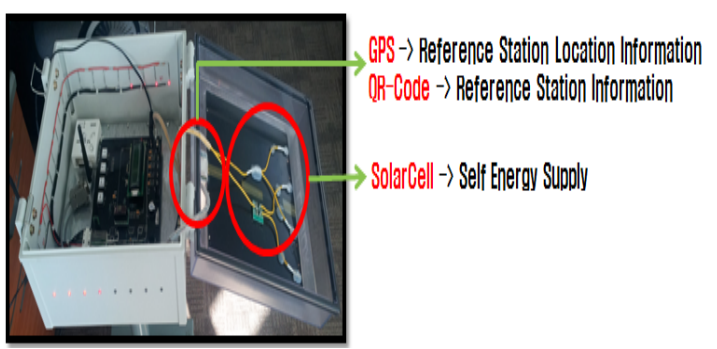

그림 8. 다기능 전자측량기준점 $\mathrm{H} / \mathrm{W}$ 상단

Fig. 8 The top of multipurpose electronic measurement reference station $\mathrm{H} / \mathrm{W}$

Solar cell을 통해 전자측량기준점에 상시적 전원을 공급할 수 있다. 그리고 상단 우측에서는 기준점을 현장 에서 식별하기 위한 $\mathrm{QR}$ 코드가 부착되어 있으며, 전자측 량기준점의 위치 데이터 확인에 필요한 GPS모듈이 부 착되어 있다. 그림 9 는 메인 컨트롤 보드로 전자측량기 준점이 설치된 원격지에서 센서 상태 및 서버와의 통신 상태를 표시해줄 수 있는 $\mathrm{LCD}$ 를 포함하고 있다. 


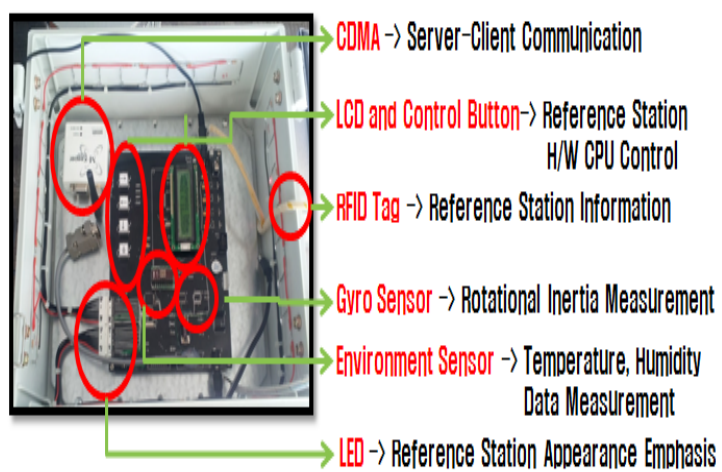

그림 9. 다기능 전자측량기준점의 메인 컨트롤 보드

Fig. 9 Main control board of multipurpose electronic measurement reference station

또한 해당 메인 컨트롤 보드에는 RFID태그 및 각 속도 측정을 위한 자이로센서 및 환경 센서를 부착하 였고, 전자 측량기준점 외형의 활용을 극대화하고자 $\mathrm{LED}$ 모듈을 부착하였다. 그림 10 은 다기능 전자측량 기준점의 하단 계패부로 Solar cell에서 충전된 태양 광 에너지를 저장하기 위한 충전지이다.

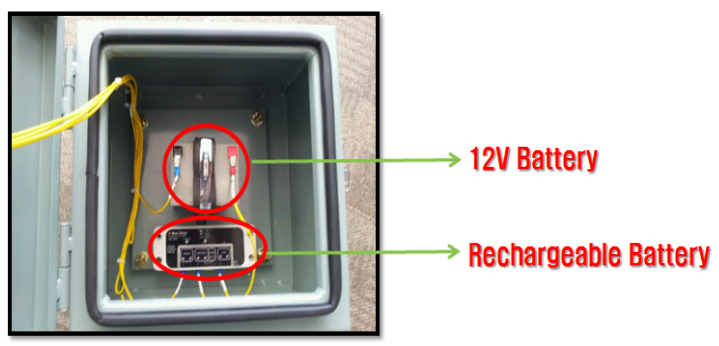

그림 10. 다기능 전자측량기준점 $\mathrm{H} / \mathrm{W}$ 하단

Fig. 10 The lower of multipurpose electronic measurement reference station $\mathrm{H} / \mathrm{W}$

발전기와 충전지로 구성되어있으며, 태양광 에너지 를 전기 에너지로 변형하는 역할을 한다. 외부물질의 유입을 차단하기 위해 이중 클립형 압착 개폐장치를 적용했다.

\section{2 성능 평가}

본 논문에서 제안하는 다기능 전자측량기준점은 기 존 전자측량기준점에 비해 다양한 형태의 전력 공급 이 필요한 점이 기존 연구와 구별된다. Solar cell을
통해 자가 전력 모듈을 제외한 6 가지의 모듈의 안정 적인 전력 공급은 반드시 필요한 조건으로 분류된다. 이를 위해 본 논문에서는 전력의 안정적인 공급을 위 해 원격지에 설치된 다기능 전자측량기준점의 배터리 전류량을 확인하였다. Solar cell의 일일 충전양의 분 석과 낮과 밤으로 나누어진 테스트를 진행하였으며, 하루를 기점으로 24 시간 측정한 값을 수치화하여 전 류량 데이터를 분석하였다. 실제 수집된 데이터의 양 은 8442건으로 10초당 한건을 수집하도록 설정해두어 8640 건을 수집해야 하지만 실제 데이터와는 약 200건 의 오차로 $2.29 \%$ 의 소실률이 발생하였다.

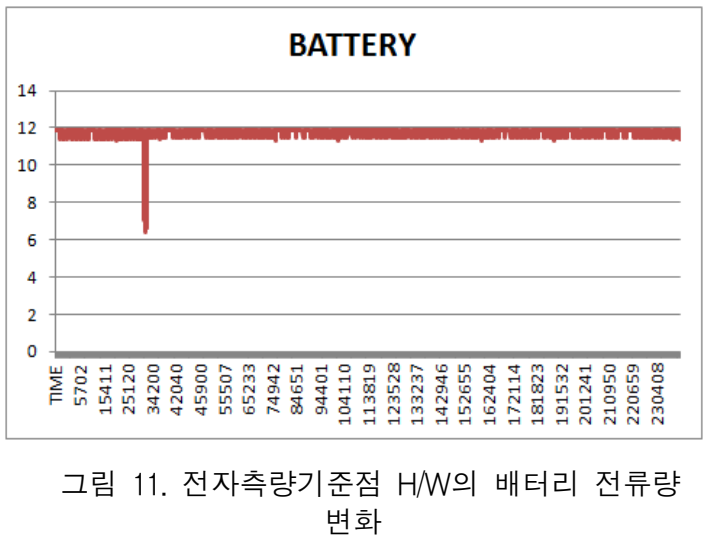

Fig. 11 Battery current capacity alteration of electronic measurement reference station $\mathrm{H} / \mathrm{W}$

그림 11 은 측량기준점 $\mathrm{H} / \mathrm{W}$ 의 배터리 전류량을 나 타내고 있다. 본 연구에서 진행된 전자측량기준점 $\mathrm{H} / \mathrm{W}$ 는 여러 모듈을 조합하여 많은 전력을 소비하고 있는 부분이 타 연구와의 차이점이다. 데이터를 지속 적으로 수집해야 하는 시스템의 특성상 외부 전력 공 급이 아닌 태양열을 이용한 안정적인 전원의 공급은 필요조건이며, 측정 결과 평균 $11.38 \mathrm{~V}$ 로 시스템의 전 원 공급에는 문제점이 발생하지 않은 결과를 나타내 었다. 하지만 야간에 일시적으로 전력효율이 떨어져 6.2 아래로 내려가 일시적으로 전원이 차단되는 현상 이 발생되었다. 이러한 문제를 실시간으로 수집되어 보여주는 $\mathrm{LCD}$, 전송을 담당하는 RS232통신, CDMA 모듈의 제어를 조절해주거나 태양광모듈 패널의 확장 을 고려해야 할 것으로 사료된다. 
$\mathrm{LED}$ 및 자이로센서를 이용한 다기능 전자측량기준점 프로토타입 시스템의 성능비교에 관한 연구

표 1. 기존 전자측량기준점과의 정성적인 비교평가

Table 1. Qualitative comparison evaluation with existing electronic measurement reference station

\begin{tabular}{|c|c|c|c|c|}
\hline Division & Study of [4] & Study of [5] & Study of [6] & Study of proposed \\
\hline Purpose of Study & $\begin{array}{l}\text { Study of Integrated } \\
\text { Reference Station } \\
\mathrm{H} / \mathrm{W} \text { and S/W }\end{array}$ & $\begin{array}{c}\text { Study of } \\
\text { Reference Station } \\
\text { Distinct }\end{array}$ & $\begin{array}{c}\text { Study of } \\
\text { Reference Station } \\
\text { Distinct }\end{array}$ & $\begin{array}{c}\text { Study of Various } \\
\text { Reference Station H/W } \\
\text { and S/W }\end{array}$ \\
\hline $\begin{array}{l}\text { Checking for } \\
\text { System }\end{array}$ & $\begin{array}{c}\text { Administrator S/W } \\
\text { and } \\
\text { Reference Station } \\
\text { H/W }\end{array}$ & $\begin{array}{l}\text { Only Reference } \\
\text { Station H/W }\end{array}$ & $\begin{array}{l}\text { Only Reference } \\
\text { Station } \mathrm{H} / \mathrm{W}\end{array}$ & $\begin{array}{l}\text { Administrator, User } \mathrm{S} / \mathrm{W} \\
\text { and } \\
\text { Reference Station } \mathrm{H} / \mathrm{W}\end{array}$ \\
\hline $\begin{array}{l}\text { Checking for } \\
\text { QR-Code and } \\
\text { RFID }\end{array}$ & Only RFID & Only QR-Code & $\begin{array}{l}\text { Both QR-Code } \\
\text { and RFID }\end{array}$ & $\begin{array}{l}\text { Both QR-Code } \\
\text { and RFID }\end{array}$ \\
\hline Checking for LED & $\mathrm{X}$ & $\mathrm{X}$ & $\mathrm{X}$ & LED \\
\hline $\begin{array}{l}\text { Checking for } \\
\text { Environment } \\
\text { Sensor }\end{array}$ & $\mathrm{X}$ & $\mathrm{X}$ & $\mathrm{X}$ & $\begin{array}{c}\text { Attachment } \\
\text { Environment Sensor }\end{array}$ \\
\hline $\begin{array}{l}\text { Checking for Gyro } \\
\text { Sensor }\end{array}$ & $\mathrm{X}$ & $\mathrm{X}$ & $\mathrm{X}$ & $\begin{array}{l}\text { Attachment } \\
\text { Gyro Sensor }\end{array}$ \\
\hline $\begin{array}{l}\text { Checking for GPS } \\
\text { Module }\end{array}$ & $\begin{array}{l}\text { Attachment } \\
\text { GPS Module }\end{array}$ & $\mathrm{X}$ & $\mathrm{X}$ & $\begin{array}{l}\text { Attachment } \\
\text { GPS Module }\end{array}$ \\
\hline $\begin{array}{l}\text { Checking for } \\
\text { Power Supply }\end{array}$ & Solar cell & $\mathrm{X}$ & $\mathrm{X}$ & Solar cell \\
\hline $\begin{array}{l}\text { Checking for } \\
\text { UI Device }\end{array}$ & Web and PDA & Smart Phone & PDA & $\begin{array}{c}\text { Web and } \\
\text { Smart Phone }\end{array}$ \\
\hline $\begin{array}{l}\text { Checking for } \\
\text { Map Support }\end{array}$ & $\begin{array}{c}\text { Only } \\
\text { Administrator UI }\end{array}$ & $\begin{array}{c}\text { Only } \\
\text { Administrator UI }\end{array}$ & $\begin{array}{c}\text { Only } \\
\text { Administrator UI }\end{array}$ & $\begin{array}{c}\text { Both } \\
\text { Administrator UI } \\
\text { and User UI }\end{array}$ \\
\hline $\begin{array}{c}\text { Communication } \\
\text { Process }\end{array}$ & CDMA & $\mathrm{X}$ & CDMA & CDMA \\
\hline Result of Study & & & $\cdots=$ & \\
\hline
\end{tabular}

4.3 타 연구와의 정성적인 비교평가

본 논문에서 제안하는 다기능 전자측량기준점은 기 존 전자측량기준점 시스템에 관한 연구의 단점을 보
안하는 것을 주된 목적으로 갖고 있다. 이를 위해 표 1 은 기존 전자측량기준점 연구와의 정성적인 비교평 가를 통해 제안된 다기능 전자측량기준점의 우수성을 
입증한다. 제안된 연구의 목적은 각종 기준점에 활용 될 $\mathrm{H} / \mathrm{W}$ 의 활용성과 $\mathrm{S} / \mathrm{W}$ 의 편의성을 개발함으로써 추후 기준점 설치 후 발생할 수 있는 문제점을 극복 하고자 한다.

표 1 에서 보는바와 같이 [5]의 연구는 각급 기준점 의 구별을 위해서 기존 기준점을 활용한 연구이다. 현 재 매설된 기준점에 $\mathrm{QR}$ 코드를 부착하여 스마트폰을 이용한 기준점 분류 시스템을 제안하였지만, 기존 기 준점에 $\mathrm{QR}$ 코드를 부착한 연구 범위를 벗어나지 못한 단점을 보여주었다. 마지막 [6]의 연구는 각급 기준점 의 구별을 위한 방법으로 관리자가 $\mathrm{PDA}$ 를 이용한 분 류 시스템을 제시하고 있다. 또한 [5]의 연구와는 다 르게 기준점을 구별하기 방법으로 $\mathrm{QR}$ 코드뿐만 아니 라 $\mathrm{RFID}$ 태그를 이용한 점을 관리자의 관리 편의성을 향상시키는 의도를 내포하고 있다. 하지만 해당 연구 역시 기존에 매설된 기준점을 활용하는 연구 범위를 벗어나지 못하였다.

본 논문에서 제안하는 연구와 상당한 연관성이 있 는 [4]의 연구는 관리자 $\mathrm{S} / \mathrm{W}$ 기반의 통합 전자측량기 준점 $\mathrm{H} / \mathrm{W}$ 를 연구하였지만 $\mathrm{H} / \mathrm{W}$ 분실 및 유실에 관 한 부분은 자이로센서를 활용한 본 연구와는 차이가 존재하였다. 그리고 본 연구에서 제안한 $\mathrm{LED}$ 모듈 기 반의 전자측량기준점 $\mathrm{H} / \mathrm{W}$ 외형과는 다르게 기준점 개발 후 별다른 활용 방안에 대한 방법을 제시하고 있지 못한 단점을 내포하고 있다.

\section{V. 결 론}

본 논문에서는 기존에 개발된 전자측량기준점의 설 치 및 관리에 대한 문제점을 파악하고 보완해야할 부 분을 체계적으로 분석한 후 다기능 전자측량기준점 $\mathrm{H} / \mathrm{W}$ 의 기능을 확장하였다. 특히 지각 변동과 지반 변 화로 인한 전자측량기준점의 손.망실 사례가 급증하여 이에 대비한 자이로센서 모듈을 이용한 전자측량기준 점을 개발하였다. 그리고 현재 매설된 기준점과 새로 설치된 전자측량기준점 외형에 대한 사후 활용도 역시 문제점으로 지적되어 $\mathrm{LED}$ 를 이용한 전자측량기준점의 활용성을 확대하였다. 또한 원격지에 매설될 전자측량 기준점의 특수성을 기반으로 별도의 전력 공급 없이 전자측량기준점에 안정적인 전력 공급을 위하여 자가
전력이 가능한 태양광모듈기반의 전력 공급 방식을 이 용하였다. 전자측량기준점 $\mathrm{H} / \mathrm{W}$ 뿐만 아니라 각급 기준 점의 관리 모니터링 $\mathrm{S} / \mathrm{W}$ 을 추가적으로 개발함으로써 기준점 관리자가 매번 매설지역에 시찰하지 않아도 체 계적인 관리가 가능하도록 시스템을 설계하였다. 이를 위해 전자측량기준점의 $\mathrm{MCU}$ 에 각종 센서 모듈과 $\mathrm{CDMA}$ 통신 모듈을 접목하여 전자측량기준점 $\mathrm{H} / \mathrm{W}$ 를 실시간으로 확인할 수 있도록 하였다.

향후 국가기준점 관리의 효율성을 도모하기 위해 현재 설계된 웹기반의 사용자 GUI와 모바일 어플리 케이션의 개발을 하고 전자측량기준점 활용의 다원화 를 위해 여러 종류의 감지 센서가 포함된 $\mathrm{PCB}$ 를 구 현할 것이다.

\section{감사의 글}

본 논문은 중소기업청에서 지원하는 2012년도 산학 연공동기술개발사업(C0036798)의 연구수행으로 인한 결과물임을 밝힙니다. 본 논문은 2013년도 한국전자 통신학회 춘계 종합학술대회 우수논문을 확장한 논 문입니다.

\section{참고 문헌}

[1] S. H. Jung, H. S. Seo, D. K. Park, C. B. Sim, "A Design of Low Cost Differential GPS System based on Web-Service", The Journal of the Korea Institute of Electronic Communication Sciences, Vol. 8, No. 3, pp. 487-498, 2013.

[2] S. Y. Yang, N. H. Yoo, C. S. Son, T. W. Lee, J. A. Kwon, W. J. Kim, "The Intelligent Guide System for Group Tourists", The Journal of the Korea Institute of Electronic Communication Sciences, Vol. 6, No. 2, pp. 304-311, 2011.

[3] S. W. Baek, H. J. Kim, "Development of a Location Tracking System for Operation Management of Public Garbage Truckst", The Journal of the Korea Institute of Electronic Communication Sciences, Vol. 6, No. 6, pp. 909-914, 2011.

[4] J. S. Cho, Y. G. Kim, Y. W. Lee, J. G. Ju, H. S. Seo, C. B. Sim, C. S. Sin, "A Implementation of Surveyed Control Point 
Management System for National Land based on RFID", The Journal of Korea Society of Digital Industry \& Information Management, Vol. 6, No. 1, pp. 13-22, 2010.

[5] I. S. Lim, J. K. Lee, "Development of the Integrated Management System of the Control Points ", The Journal of Korean Society for GeoSpatial Information System, Vol. 12, No. 4, pp. 45-51, 2004.

[6] Y. S. Oh, Y. K. Lee, J. Min. Park, "Development of Remote Monitoring Web System for National Control Points using RFID Tags", The Journal of GIS Association of Korea, Vol. 15, No. 3, pp. 237-249, 2007.

[7] S. K Park, S. H. Jung, M. J. Oh, D. W. Park, C. B. Sim, "Qualitative Performance Comparison of Multipurpose Virtual Reference Station Hardware using LED and QR Code", The Academic Conference of the Korea Institute of Electronic Communication Sciences, Vol. 7, No. 1, pp. 20-23, 2013.

$$
\text { 저자 소개 }
$$

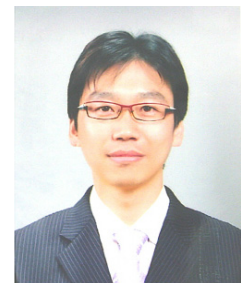

\section{박성균(Sung-Kyun Park)}

2002년 2월 진주산업대학교 전자공 학과 졸업 (공학사)

2012년 3월 현재 순천대학교 대학 원 멀티미디어공학과 재학(석사과정)

(주)휴머닉스 대표이사

※ 관심분야 : $\mathrm{PCB}$ 설계 및 제작, 신재생 에너지, 시 스템 $\mathrm{H} / \mathrm{W}$ 테스팅

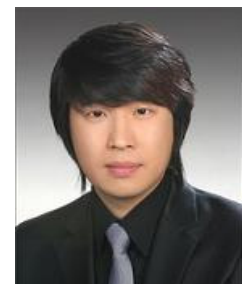

\section{정세훈(Se-Hoon Jung)}

2010년 2월 순천대학교 멀티미디어 공학과 졸업(공학사)

2012년 2월 순천대학교 대학원 멀 티미디어공학과 졸업(공학석사)

2012년 3월 현재 순천대학교 대학원 멀티미디어공 학과 재학(박사과정)

※ 관심분야 : 모바일 클라우드, 상황인식, 객체지향 설계 모델링

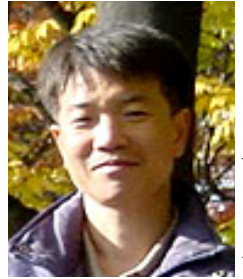

\section{박동국(Dong-Gook Park)}

1986년 2월 경북대학교 전자공학과 졸업(공학사) 1989년 2월 KAIST 전기및전자공학 과 졸업(공학석사)

2001년 호주 QUT(Queensland Univ. of Tech.) School of Data Communications(공학박사)

2004년 현재 순천대학교 정보통신공학과 부교수 ※ 관심분야 : 정보보호, 보안 시스템, 보안 기법 및 유비쿼터스 컴퓨팅

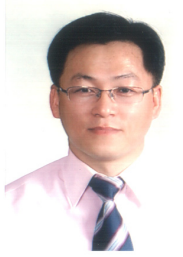

\section{심춘보(Chun-Bo Sim)}

1996년 2월 전북대학교 컴퓨터공학 과 졸업(공학사)

1998년 2월 전북대학교 대학원 컴 퓨터공학과 졸업(공학석사)

2003년 2월 전북대학교 대학원 컴퓨터공학과 졸업(공 학박사)

2005년 현재 순천대학교 멀티미디어공학과 부교수 ※ 관심분야 : 멀티미디어 $\mathrm{DB} \& \mathrm{IR}$, 유비쿼터스 컴 퓨팅 
